\title{
DEFINING THE UTILITY AND MARKET VALUE OF A REAL ESTATE: A MULTIPLE CRITERIA APPROACH
}

\author{
Artūras KAKLAUSKAS ${ }^{1}$, Edmundas K. ZAVADSKAS ${ }^{2}$, Audrius BANAITIS ${ }^{1}$, \\ Gintautas ŠAKAUSKAS ${ }^{1}$ \\ 1 Department of Construction Economics and Property Management, Vilnius Gediminas \\ Technical University, Sauletekio al. 11, LT-10223 Vilnius, Lithuania \\ E-mail: Arturas.Kaklauskas@st.vtu.lt \\ 2 Department of Construction Technology and Management, Vilnius Gediminas \\ Technical University, Sauletekio al. 11, LT-10223 Vilnius, Lithuania \\ E-mail: Edmundas.Zavadskas@adm.vtu.lt
}

Received 8 September 2006; accepted 15 December 2006

\begin{abstract}
This paper considers the application of methodology for the defining the utility and market value of a real estate. The theoretical basis of the methodology is developed. The proposed methods, the method of multiple criteria complex proportional assessment (COPRAS) and the method of defining the utility and market value of a real estate assume the dependence of priority, utility degree and value of investigated versions on a system of criteria adequately describing the alternatives and their direct proportionality to the values and weights of these criteria. The procedure of the defining the utility and market value of a real estate is discussed using an example.
\end{abstract}

KEYWORDS: Multiple criteria analysis; Utility and market value; Real estate

\section{INTRODUCTION}

Many decision making models and methods have been developed in the world for solving different problems in real estate sector. Kuo (1996) proposed a method of polynomial approximation to value the housing price dynamics and the valuation of mortgage default options. Gonzalez and Laureano-Ortiz (1992) concentrated on the issues involved in the application of the case-based reasoning techniques to a specific domain, property appraisal. Casebased reasoning has been recently favored because it seems to resemble more closely the psychological process humans follow when trying to apply their knowledge to the solution of problems: adapting solutions of similar prob- lems handled in past experiences to address present situations. By modelling the market data approach of appraisal, using adaptations of case-based reasoning techniques, such as the similarity links and the critics, and integrating other techniques, (i.e., the use of comfort factors), a case-based reasoner for property appraisal is implemented addressing the issues just mentioned above (Gonzalez and Laureano-Ortiz, 1992).

Diappi and Bolchi (2007) investigated local housing market dynamics by applying an urban spatial model of gentrification based on Smith's rent gap theory. Smith's supply side approach explains the emergence of gentrifying neighbourhoods on the basis of investments spent in "large scale renewal

International Journal of Strategic Property Management

ISSN 1648-715X print / ISSN 1648-9179 online @ 2007 Vilnius Gediminas Technical University

http://www.ijspm.vgtu.lt 
projects" which only investors or developers looking for profits are able to carry out. They invest in degraded areas on the base of the gap between the actual rent and the potential rent after rehabilitation (rent gap). A set of factors are selected and a statistical earlywarning method, which can monitor the Shenzhen real estate property market, is developed by Huang and Wang (2005). In addition, a system dynamics model has been developed, which can provide a simulation tool to predict the effect of regulatory policies on the real estate market. Evaluation results indicate that the pre-warning system can provide useful information to regulate the property market in Shenzhen.

Markland (1979) described a Monte Carlo simulation approach to the analysis of real estate investments under uncertainty. Wang (2005) described a knowledge-based decision support system for measuring the performance of government real estate investment using DEA models. Trippi (1989) examined industry factors, design goals, and functions of a system used to improve major real property asset acquisition, improvement, and divestment decisions. Fletcher et al. (2000) were concerned as to whether it is more appropriate to use aggregate or disaggregate models in forecasting house prices when using hedonic modeling. Baffoe-Bonnie (1998) analyzed the dynamic effects of four key macroeconomic variables on housing prices and the stock of houses sold at national and regional levels by using a nonstructural estimation technique. Hui and $\mathrm{Yu}$ (2006) analyzed the dynamics of Hong Kong's office rental market. This study provides a generator approach, on the basis of both system dynamics and econometric modeling. Dua et al. (1999) used Bayesian vector autoregressive models to examine the usefulness of leading indicators in predicting U.S. home sales. Wheaton et al. (1997) applied structural econometric methodology for estimating and forecasting the greater London office market. Magdisyuk (2001) considered some aspects of using a cascade-correlation network in the in- vestment task, in which it is required to determine the most suitable project to invest money. Leung and Hui (2000) attempted to introduce the application of the option pricing theory to the valuation of property development projects by integrating both the capital budgeting and the strategic planning that were based on the London Docklands saga.

Lins et al. (2005) proposes a new methodology for the assessment of the value range for real estate units. The proposed approachchristened Double Perspective-Data Envelopment Analysis (DP-DEA) - is applied to a database comprising the prices and features of the units under assessment. It is shown that the DP-DEA presents some specific advantages when compared to the usual regression analysis method employed in real estate value assessment. Englund et al. (1998) presented an improved methodology for estimating asset prices for real estate and other durables. The method is used to analyze house price dynamics by exploiting an unusually rich and detailed body of data-extensive descriptive and financial information on every house sale in Sweden during a 12-year period.

Cannaday et al. (2005) developed a multivariate repeat-sales model that is able to separately control for the effects of age and time, as well as other assets with changing attributes in the construction of price indices. Martinaitis et al. (2007) proposed a two-factor method for appraising building renovation and energy efficiency improvement projects. Ioannides (2003) examined effects of social interactions in the form of reaction functions for homeowners' valuation of their properties at the level of the immediate residential neighborhood, with neighborhoods consisting of a randomly chosen dwelling unit and about ten nearest neighbors. The paper provides empirical support for the notion, common in the real estate world, of the importance of neighboring properties in property valuations. Gibbons and Machin (2003) provided the first empirical evidence for the UK on the effect of primary school performance on property prices. 
Bourassa et al. (2006) presented the sale price appraisal ratio (SPAR) method for constructing house price indexes. Authors compared the official New Zealand indexes for three urban areas with repeat sales and hedonic indexes created from the same transactions data, and observed that the SPAR method produced an index very much like those produced by repeat sales methods.

Mendez (2006) estimated the value of legal property titles on the Costa Rican urban housing market using hedonic regressions on the value of the house and then studied specific segments of the population that vary in their economic activities and incentives as related to legal housing titles. Arguea and Hsiao (2000) presented a latent variable framework to provide consistent and efficient estimates of market values of amenities. They used samples obtained from the American Housing Survey (AHS) to estimate the effect of neighborhood quality on housing prices.

However, fewer attempts have been made to employ methods of multiple criteria decision making (MCDM) to solve a number of problems in real estate sector (see Zavadskas and Kaklauskas, 1996; Zavadskas et al., 1997; Malienè et al., 1999; Zavadskas et al., 2001; Zavadskas et al., 2004a; Zavadskas et al., 2004b; Kaklauskas and Gikys, 2005; Kaklauskas et al., 2005). In this paper, the authors present a methodology for the defining the utility and market value of a real estate. The proposed methods, the method of multiple criteria complex proportional assessment (COPRAS) and the method of defining the utility and market value of a real estate assume the dependence of priority, utility degree and value of investigated versions on a system of criteria adequately describing the alternatives and their direct proportionality to the values and weights of these criteria. The potential of the approach has been explored in Framework 5 (2000), Framework 5 (2001), Framework 6 (2003) and ACE PHARE programme (Kaklauskas, 1998), for instance. Realworld applications demonstrate the effective- ness of this approach in solving wide-range problems (see Ministry of Construction and Urban Development of the Republic of Lithuania, 1998; Ministry of Economy of the Republic of Lithuania, 2001). In view of our theoretical and practical results, we believe that the proposed approach is especially suitable for decision contexts where multiple dimensions of problems must be evaluated and due attention to interests of participants involved must be given. The proposed methodology allows the decision maker to negotiate his/her preferences and needs.

The remainder of this paper is structured as follows. Section 2 presents the methodology for the determination of the utility degree and market value of a real estate. An example is given in Section 3 to illustrate the use of the methodology. Finally, some concluding remarks are provided in Section 4.

\section{A MULTIPLE CRITERIA APPROACH}

\subsection{Collection of initial data and determination of the criteria weights}

The determination of the utility degree and market value of the real estate under investigation and the establishment of the order of priority for its implementation has less difficulty if the criteria numerical values and weights are obtained and when multiple criteria decision making methods are used.

The data for the analysis of real estate projects are presented as a grouped decision matrix that involves a set of $n$ alternatives, to be compared with respect to a set of $m$ criteria (Table 1). For evaluating competing alternatives (the real estate to be valued and comparable real estates), a complex analysis of its economical, technical, qualitative, infrastructure and other aspects is needed. Quantitative and conceptual descriptions provide this information. Quantitative information is based on criteria system, units of measurement, values and weights of the criteria. The determination of quantitative criteria numerical values is 
based on the use of various statistical methods, analysed projects, recommendations, pricelists, reference books, building codes, specifications and other documents.

The diversity of aspects being assessed should include a variety of presented data needed to decide. Therefore, the conceptual information may be presented in numerical, textual, graphical, and audio/video format. The conceptual descriptions of criteria and reasons for a choice of the criteria's system, their values and weights should all be analyzed. Conceptual information is needed to make more complete and accurate evaluation of the real estate alternatives considered. It also helps to get more useful information as well as developing a system and subsystems of criteria and defining their values and weights.

In order to define the utility degree and market value of a real estate, it is necessary, to have formed the decision matrix, to perform multiple criteria analysis. MCDM refers to making preference decisions on the competing alternatives (the real estate to be valued and comparable real estates) in terms of multiple criteria. Typically, each alternative is evaluated on the established set/system of criteria. One of the major tasks is to determine the weights of the criteria. This is most often done with the use of experts' assessments.

Having determined the weights of criteria by a panel of experts, we express our preferences in terms of the relative importance of criteria. With a change of values of quantitative criteria, their weight changes as well. The method developed by the authors (Kaklauskas, 1996; Kaklauskas, 1999) takes into account criteria's quantitative and qualitative aspects.

\subsection{A method of multiple criteria complex proportional assessment}

The method of multiple criteria complex proportional assessment (COPRAS) (Zavadskas and Kaklauskas, 1996), presented here, uses a stepwise ranking and evaluating procedure of the alternatives in terms of significance and utility degree.

Table 1. Grouped decision matrix of a multiple criteria analysis of the real estate to be valued

\begin{tabular}{|c|c|c|c|c|c|c|c|c|c|}
\hline \multirow[t]{2}{*}{ Criteria } & \multirow[t]{2}{*}{$*$} & \multirow[t]{2}{*}{ Weights } & \multirow{2}{*}{$\begin{array}{l}\text { Measuring } \\
\text { units }\end{array}$} & \multicolumn{6}{|c|}{ Real estate to be valued and comparable real estates } \\
\hline & & & & $a_{1}$ & $a_{2}$ & $\ldots$ & $a_{j}$ & $\ldots$ & $a_{n}$ \\
\hline \multicolumn{10}{|c|}{ Quantitative criteria } \\
\hline$X_{1}$ & $z_{1}$ & $q_{1}$ & $m_{1}$ & $x_{11}$ & $x_{12}$ & $\ldots$ & $x_{1 j}$ & $\ldots$ & $x_{1 n}$ \\
\hline$X_{2}$ & $z_{2}$ & $q_{2}$ & $m_{2}$ & $x_{21}$ & $x_{22}$ & $\ldots$ & $x_{2 j}$ & $\ldots$ & $x_{2 n}$ \\
\hline$\ldots$ & $\ldots$ & $\ldots$ & $\ldots$ & $\ldots$ & $\ldots$ & $\ldots$ & $\ldots$ & $\ldots$ & $\ldots$ \\
\hline$X_{i}$ & $z_{i}$ & $q_{i}$ & $m_{i}$ & $x_{i 1}$ & $x_{i 2}$ & $\ldots$ & $x_{i j}$ & $\ldots$ & $x_{\text {in }}$ \\
\hline$\ldots$ & $\ldots$ & $\ldots$ & $\ldots$ & $\ldots$ & $\ldots$ & $\ldots$ & $\ldots$ & $\ldots$ & $\ldots$ \\
\hline$X_{t}$ & $z_{t}$ & $q_{t}$ & $m_{t}$ & $x_{t 1}$ & $x_{t 2}$ & $\ldots$ & $x_{t j}$ & $\cdots$ & $x_{t n}$ \\
\hline \multicolumn{10}{|c|}{ Qualitative criteria } \\
\hline$X_{t+1}$ & $z_{t+1}$ & $q_{t+1}$ & $m_{t+1}$ & $x_{t+11}$ & $x_{t+12}$ & $\cdots$ & $x_{t+1 j}$ & $\cdots$ & $x_{t+1 n}$ \\
\hline$X_{t+2}$ & $z_{t+2}$ & $q_{t+2}$ & $m_{t+2}$ & $x_{t+21}$ & $x_{t+22}$ & $\cdots$ & $x_{t+2 j}$ & $\cdots$ & $x_{t+2 n}$ \\
\hline$\ldots$ & $\ldots$ & $\ldots$ & $\ldots$ & $\ldots$ & $\ldots$ & $\ldots$ & $\ldots$ & $\ldots$ & $\ldots$ \\
\hline$X_{m}$ & $z_{m}$ & $q_{m}$ & $m_{m}$ & $x_{m 1}$ & $x_{m 2}$ & $\ldots$ & $x_{m j}$ & $\ldots$ & $x_{m n}$ \\
\hline \multicolumn{10}{|c|}{ Conceptual information pertinent to real estate (texts, drawings, graphics, tapes) } \\
\hline$C_{f}$ & $C_{z}$ & $C_{q}$ & $C_{m}$ & $C_{1}$ & $C_{2}$ & $\ldots$ & $C_{j}$ & $\ldots$ & $C_{n}$ \\
\hline
\end{tabular}

* - The $\operatorname{sign} z_{i}(+(-))$ indicates that a greater/lesser criterion value corresponds to a greater weight for a client 
The procedure of the method of complex proportional evaluation consists of the following steps:

(1) Calculation of the weighted normalized decision matrix (Table 2). The purpose of this step is to receive dimensionless weighted values from the comparative indexes. When the dimensionless values of the indexes are known, all criteria, originally having different dimensions, can be compared. The weighted normalized value $d_{i j}$ is calculated as

$$
d_{i j}=\frac{x_{i j} \cdot q_{i}}{\sum_{j=1}^{n} x_{i j}}, \quad i=1, \overline{1, m} ; \quad j=1, n .
$$

where: $x_{i j}$ is the value of the $i$ criterion in the $j$ alternative of a solution; $m$ is the number of criteria; $n$ is the number of the alternatives compared; $q_{i}$ is weight of $i$ criterion.

The sum of dimensionless weighted index values $d_{i j}$ of each criterion $x_{i}$ is always equal to the weight $q_{i}$ of this criterion

$$
q_{i}=\sum_{j=1}^{n} d_{i j}, \quad i=\overline{1, m} ; j=\overline{1, n}
$$

In other words, the value of weight $q_{i}$ of the investigated criterion is proportionally distributed among all alternative versions $a_{j}$ according to their values $x_{i j}$.

(2) Calculation of the sums of maximizing indexes $\left(S_{+j}\right)$ and minimizing indexes $\left(S_{-j}\right)$ describing the real estate. The lower value of minimizing indexes is better (price of the plot and building, etc.). The greater value of maximizing indexes is better (comfortability and aesthetics of the building, etc.). The values $S_{+j}$ and $S_{-j}$ are calculated as

$$
\begin{aligned}
& S_{+j}=\sum_{i=1}^{m} d_{+i j} ; \quad S_{-j}=\sum_{i=1}^{m} d_{-i j}, \\
& i=\overline{1, m} ; j=\overline{1, n} .
\end{aligned}
$$

\begin{tabular}{|c|c|c|c|c|c|c|c|c|}
\hline \multirow[t]{2}{*}{ Criteria } & \multirow[t]{2}{*}{$*$} & \multirow[t]{2}{*}{ Weights } & \multicolumn{6}{|c|}{ Real estate to be valued and comparable real estates } \\
\hline & & & $a_{1}$ & $a_{2}$ & $\ldots$ & $a_{j}$ & $\ldots$ & $a_{n}$ \\
\hline$X_{1}$ & $z_{1}$ & $q_{1}$ & $d_{11}$ & $d_{12}$ & $\ldots$ & $d_{1 j}$ & $\ldots$ & $d_{1 n}$ \\
\hline$X_{2}$ & $z_{2}$ & $q_{2}$ & $d_{21}$ & $d_{22}$ & $\cdots$ & $d_{2 j}$ & $\cdots$ & $d_{2 n}$ \\
\hline$\ldots$ & $\ldots$ & $\ldots$ & $\ldots$ & $\ldots$ & $\ldots$ & $\ldots$ & $\ldots$ & $\ldots$ \\
\hline$X_{i}$ & $z_{i}$ & $q_{i}$ & $d_{i 1}$ & $d_{i 2}$ & $\ldots$ & $d_{i j}$ & $\ldots$ & $d_{\text {in }}$ \\
\hline$\ldots$ & $\ldots$ & $\ldots$ & $\ldots$ & $\ldots$ & $\ldots$ & $\ldots$ & $\ldots$ & $\ldots$ \\
\hline$X_{t}$ & $z_{t}$ & $q_{t}$ & $d_{t 1}$ & $d_{t 2}$ & $\ldots$ & $d_{t j}$ & $\ldots$ & $d_{t n}$ \\
\hline$\ldots$ & $\ldots$ & $\ldots$ & $\ldots$ & $\ldots$ & $\ldots$ & $\ldots$ & $\ldots$ & $\ldots$ \\
\hline$X_{t+1}$ & $z_{t+1}$ & $q_{t+1}$ & $d_{t+11}$ & $d_{t+12}$ & $\ldots$ & $d_{t+1 j}$ & $\ldots$ & $d_{t+1 n}$ \\
\hline$X_{t+2}$ & $z_{t+2}$ & $q_{t+2}$ & $d_{t+21}$ & $d_{t+22}$ & $\ldots$ & $d_{t+2 j}$ & $\ldots$ & $d_{t+2 n}$ \\
\hline$\ldots$ & $\ldots$ & $\ldots$ & $\ldots$ & $\ldots$ & $\ldots$ & $\ldots$ & $\ldots$ & $\ldots$ \\
\hline$X_{i}$ & $z_{i}$ & $q_{i}$ & $d_{i 1}$ & $d_{i 2}$ & $\ldots$ & $d_{i j}$ & $\ldots$ & $d_{\text {in }}$ \\
\hline$\ldots$ & $\ldots$ & $\ldots$ & $\ldots$ & $\ldots$ & $\ldots$ & $\ldots$ & $\ldots$ & $\ldots$ \\
\hline$X_{m}$ & $z_{m}$ & $q_{m}$ & $d_{m 1}$ & $d_{m 2}$ & $\ldots$ & $d_{m j}$ & $\ldots$ & $d_{m n}$ \\
\hline The sums of weighted normalized maximizing indices & of the & real estate & $S_{+1}$ & $S_{+2}$ & $\ldots$ & $S_{+j}$ & $\ldots$ & $S_{+n}$ \\
\hline The sums of weighted normalized minimizing indices & of the & real estate & $S_{-1}$ & $S_{-2}$ & $\ldots$ & $S_{-j}$ & $\ldots$ & $S_{-n}$ \\
\hline Significance of the real estate & & & $Q_{1}$ & $Q_{2}$ & $\ldots$ & $Q_{j}$ & $\ldots$ & $Q_{n}$ \\
\hline Real estate's priorities & & & $\operatorname{Pr}_{1}$ & $\mathrm{Pr}_{2}$ & & $P r_{j}$ & & $P r_{n}$ \\
\hline Real estate's utility degree $(\%)$ & & & $N_{1}$ & $N_{2}$ & $\ldots$ & $N_{j}$ & $\ldots$ & $N_{n}$ \\
\hline
\end{tabular}

In this case, the values $S_{+j}$ (the greater is this value, the more satisfied are the interested

Table 2. Multiple criteria analysis of the real estate

\footnotetext{
* - The $\operatorname{sign} z_{i}(+(-))$ indicates that a greater/lesser criterion value corresponds to a greater weight for a client
} 
parties) and $S_{-j}$ (the lower is this value, the better is goal attainment by the interested parties) express the degree of goals attained by the interested parties in each alternative. In any case the sums of 'pluses' $S_{+j}$ and 'minuses' $S_{-j}$ of all alternatives is always respectively equal to all sums of weights of maximizing and minimizing criteria

$$
\begin{aligned}
& S_{+}=\sum_{j=1}^{n} S_{+j}=\sum_{i=1}^{m} \sum_{j=1}^{n} d_{+i j}, \\
& S_{-}=\sum_{j=1}^{n} S_{-j}=\sum_{i=1}^{m} \sum_{j=1}^{n} d_{-i j}, \\
& i=\overline{1, m} ; j=\overline{1, n} .
\end{aligned}
$$

In this way, the calculations made may be additionally checked.

(3) Determination of the significance of the alternative based on positive and negative characteristics. The relative significance $Q_{j}$ of each alternative $j$ is defined as

$$
Q_{j}=S_{+j}+\frac{S_{-\min } \cdot \sum_{j=1}^{n} S_{-j}}{S_{-j} \cdot \sum_{j=1}^{n} \frac{S_{-\min }}{S_{-j}}}, \quad j=\overline{1, n} .
$$

(4) Determination of the priority of the real estate. The greater significance $Q_{j}$, the higher is the priority (rank) of the real estate. The relative significance $Q_{j}$ of real estate $j$ indicates the satisfaction degree of the needs of the interested parties. In the case of $Q_{\max }$, the satisfaction degree is the highest. The relative significance of other real estate is lower, and the needs of the interested parties and the real estate are satisfied to a smaller extent than in the best real estate.

\subsection{A method of defining the utility and market value of a real estate}

The degree of real estate utility is directly associated with quantitative and conceptual information related to it. If one real estate is characterized by the best comfortability, aesthetics, price indices, while the other shows better maintenance and facilities management characteristics, both having obtained the same significance values as a result of multiple criteria evaluation, this means that their utility degree is also the same. With the increase (decrease) of the significance of a real estate analyzed, its degree of utility also increases (decreases). The degree of real estate utility is determined by comparing the analyzed real estate with the best real estate. The values of the utility degree are from $0 \%$ to $100 \%$ between the worst and the best real estate alternatives.

The degrees of utility of the real estate considered as well as the market value of a real estate being valuated are determined in seven steps:

(1) The utility degree $N_{j}$ of each real estate alternative $a_{j}$ is calculated as

$$
N_{j}=\left(Q_{j}: Q_{\max }\right) \cdot 100 \%,
$$

where: $Q_{j}$ and $Q_{\max }$ are the significances of the real estate obtained from the equation 5 .

The degree of utility $N_{j}$ of real estate $a_{j}$ indicates the level of satisfying the needs of the parties interested in the real estate. The more goals are achieved and the more important they are, the higher is the degree of the real estate utility. Since clients are mostly interested in how much more efficient particular real estate are than the others (which ones can better satisfy their needs), then it is more advisable to use the concept of real estate utility rather than significance when choosing the most efficient solution.

A degree of real estate utility reflects the extent to which the goals pursued by the interested parties are attained. Therefore, it may be used as a basis for determining real estate market value. The more objectives are attained and the more significant they are the higher will be real estate degree of utility and its market value. 
Thus, having determined in such a way the ratio of degree of utility and market value of real estate, one can see what complex effect can be obtained by investing money into anyone of the real estate. There is a complete clarity where it pays better to invest the money and what is the efficiency degree of the investment.

(2) Calculation of the efficiency degree $E_{x j}$ of money invested into real estate $a_{j}$. It shows by how many percent it is better (worse) to invest money into real estate $a_{x}$ compared with real estate $a_{j}$. The efficiency degree $E_{x j}$ is calculated as

$$
E_{x j}=N_{x}-N_{j},
$$

(3) Calculation of the mean deviation $k_{x}$ of the utility degree $N_{x}$ of the real estate $a_{x}$ from the same index of other real estate $(n-1)$ (Table 3). The mean deviation $k_{x}$ is calculated as

$$
k_{x}=\sum_{j=1}^{n} E_{x j}:(n-1) \text {, }
$$

(4) The initial value of the real estate being valuated is calculated as

$$
x_{11}=\sum_{j=2}^{n} x_{1 j}:(n-1)
$$

In grouped decision matrix (Table 1), the real estate $\alpha_{1}$ to be valuated should be assigned the market value $\left(x_{11-R}\right)$. Other comparison standard real estate $\left(a_{2}-a_{n}\right)$ were sold, their purchasing/selling prices $\left(x_{12}-x_{1 n}\right)$ known. All the values and weights of the criteria relating to other real estate are also known.

The problem may be stated as follows: what market value $x_{11-R}$ of the valuated real estate $a_{1}$ will make it equally competitive on the market with comparison standard real estate $\left(a_{2^{-}}\right.$ $\left.a_{n}\right)$ ? This may be determined if a complex analysis of the benefits and drawbacks of the real estate is made.

Using a grouped decision matrix (Table 1) and the equations 1-9 the calculations are made.

(5) The corrected value $x_{11-p}$ of the real estate to be valuated $a_{1}$ is calculated as

$$
x_{11-p}=x_{11}\left(1+k_{1} \div 100\right) \text {, }
$$

(6) Determination whether the corrected value $x_{11-R}$ of the real estate being valuated $a_{1}$ had been calculated accurately enough

$$
\left|k_{1}\right|<s
$$

where: $s$ is the accuracy, \%, to be achieved in calculating the market value $x_{11-p}$ of the real estate $a_{1}$.

(7) Determination of the market value $x_{11}$ ${ }_{R}$ of the real estate $a_{1}$ to be valuated. If inequality 11 is satisfied the market value of the real estate $a_{1}$ may be found as

$$
x_{11-R}=x_{11-p}
$$

If inequality 11 is not satisfied this means that the value of the real estate being valuated

Table 3. Calculation of mean deviations of the real estate utility degrees

\begin{tabular}{lllllll}
\hline $\begin{array}{l}\text { Real estate } \\
\text { considered }\end{array}$ & \multicolumn{3}{l}{$\begin{array}{l}\text { Utility degree deviation of the real estate analyzed } \\
\text { compared to other real estate, \% }\end{array}$} & $\begin{array}{l}\text { Mean deviation } k_{x} \text { of utility degree } N_{x} \text { of } \\
\text { the real estate } a_{x} \text { compared to other }(n-1) \\
\text { real estates, \% }\end{array}$ \\
\cline { 2 - 6 } & $a_{1}$ & $a_{2}$ & $a_{3}$ & $\ldots$ & $a_{n}$ & \\
\hline$a_{1}$ & 0 & $E_{12}$ & $E_{13}$ & $\ldots$ & $E_{1 n}$ & $k_{1}$ \\
$a_{2}$ & $E_{21}$ & 0 & $E_{23}$ & $\ldots$ & $E_{2 n}$ & $k_{2}$ \\
$a_{3}$ & $E_{31}$ & $E_{32}$ & 0 & $\ldots$ & $E_{3 n}$ & $k_{3}$ \\
$\ldots$ & $\ldots$ & $\ldots$ & $\ldots$ & $\ldots$ & $\ldots$ & $\ldots$ \\
$a_{j}$ & $E_{j 1}$ & $E_{j 2}$ & $E_{j 3}$ & $\ldots$ & $E_{j n}$ & $k_{j}$ \\
$\ldots$ & $\ldots$ & $\ldots$ & $\ldots$ & $\ldots$ & $\ldots$ & $\ldots$ \\
$a_{n}$ & $E_{n 1}$ & $E_{n 2}$ & $E_{n 3}$ & $\ldots$ & 0 & $k_{n}$ \\
\hline
\end{tabular}


had not been calculated accurately enough and the approximation cycle should be repeated. In this case, the corrected value $x_{11}=x_{11-p}$ of the real estate being valuated is substituted into a grouped decision making matrix of real estate multiple criteria analysis and the calculations according to the equations 1-10 should be repeated until the inequation 11 is satisfied.

\section{ESTIMATION OF THE MARKET VALUE FOR THE SINGLE-FAMILY DWELLING}

In the sales comparison approach, market value is estimated by comparing properties similar to the subject real estate that have recently been sold, are listed for sale, or are under contract. A major premise of the sales comparison approach is that the market value of a real estate is directly related to the prices of comparable, competitive properties. The value difference between two properties is calculated by multiplication of the differences in the characteristics considered, with marginal adjustment factors for those characteristics.

A sample valuation case study is analyzed in order to illustrate the use of the multiple criteria approach presented above. Two comparable single-family dwellings were selected for the single-family dwelling being valued. Both are located in Vilnius. The single-family dwelling being valued and the comparable single-family dwellings contain differences in quality, quantity and market conditions. When drawing up the system of criteria describing the single-family dwelling being valued and the comparable single-family dwellings, it is worthwhile to take into account the suggestions of other authors as well. Data for the determination of the system of criteria and their weights of the single-family dwelling being valued and the comparable single-family dwellings were collected by the questionnaires that were mailed to experts in Lithuania, based on the use of suggestions of experts, as well as reference books and recommendations. For exam- ple, the 35 experts were asked to prioritize the 28 criteria listed in Table 4. The respondents were property scientists, real estate appraisers, brokers, and other specialists. The determination of quantitative criteria values is based on the use of analyzed projects, pricelists, specifications, reference books and recommendations.

The description of the single-family dwelling being valued and the comparable singlefamily dwellings is presented further on in this paper.

\subsection{Description of the single-family dwelling being valued}

The single-family dwelling under valuation here, are located on district Bukciai in Vilnius, 5 kilometers from the city center, next to the river Neris $(0.5 \mathrm{~km}) .7$ ares cover an area of plot situated at Ruko Street, the ground of which is clay loam. Form of plot is a regular rectangle; the plot is bounding to neighboring plots from three sides. The built area of the plot covers $130 \mathrm{~m}^{2}$, number of stores - two, the dwelling house is brick-built with economic heat insulation, but still under installation, external finishing is completed $60 \%$, two telephone lines are installed. Modern and up-todate construction materials were used. A garage is equipped near the house. The total floor-space of the building makes up $260 \mathrm{~m}^{2}$. The dwelling house is in good condition. Engineering lines are municipal.

The initial market value (selling price) of the single-family dwelling under investigation $\left(x_{11}=380.00\right.$ thousand EURO, 1 EURO is equal to 3.4528 LTL) was accepted according to the developed maps of real estate values.

\subsection{Description of the first comparable single-family dwelling}

The comparable single-family dwelling is located on district Bukciai in Vilnius, 5 kilometers from the city center, next to the river Neris $(0.5 \mathrm{~km}) .13$ ares cover an area of a plot of land situated at Ruko Street, the 
Table 4. Grouped decision matrix of a multiple criteria analysis of a single-family dwellings

\begin{tabular}{|c|c|c|c|c|c|c|c|}
\hline \multirow[t]{2}{*}{ No. } & \multirow[t]{2}{*}{ Criteria } & \multirow[t]{2}{*}{$*$} & \multirow{2}{*}{$\begin{array}{l}\text { Measuring } \\
\text { units }\end{array}$} & \multirow[t]{2}{*}{ Weights } & \multicolumn{3}{|c|}{ Comparable single-family dwellings } \\
\hline & & & & & 1 & 2 & 3 \\
\hline 1. & Selling price & - & 1000 EURO & 0.8040 & 380.00 & 360.00 & 410.00 \\
\hline 2. & Area of land plot & + & Ares & 0.2786 & 7.00 & 13.00 & 6.00 \\
\hline 3. & Constructed area of land plot & + & Ares & 0.0436 & 1.3 & 1.6 & 1.2 \\
\hline 4. & Quality of engineering equipment, completeness & + & Points & 0.1138 & 0.50 & 0.70 & 0.90 \\
\hline 5. & Accessability to land plot & + & Points & 0.1063 & 0.80 & 0.90 & 1.00 \\
\hline 6. & Infrastructure of education and public welfare & + & Points & 0.0372 & 0.80 & 0.80 & 0.80 \\
\hline 7. & Industrial territories & - & Points & 0.0464 & 0.01 & 0.01 & 0.01 \\
\hline 8. & Local commercial infrastructure & + & Points & 0.0070 & 0.80 & 0.80 & 0.80 \\
\hline 9. & Neighborhood & + & Points & 0.0933 & 1.00 & 1.00 & 1.00 \\
\hline 10. & District prestige & + & Points & 0.0877 & 0.60 & 0.60 & 0.60 \\
\hline 11. & Pollution (emission) & - & Points & 0.1289 & 0.50 & 0.50 & 0.50 \\
\hline 12. & Total floor space & + & Sq. m & 0.1686 & 260.00 & 280.00 & 240.00 \\
\hline 13. & Age of dwelling & - & Years & 0.0837 & 2.00 & 3.00 & 4.00 \\
\hline 14. & Layout of premises & + & Points & 0.0446 & 0.40 & 0.40 & 0.80 \\
\hline 15. & Structures, their state & + & Points & 0.1038 & 1.00 & 1.00 & 1.00 \\
\hline 16. & Comfortability & + & Points & 0.0564 & 0.40 & 0.40 & 0.90 \\
\hline 17. & Internal decoration & + & Points & 0.1124 & 0.30 & 0.70 & 0.80 \\
\hline 18. & External decoration & + & Points & 0.1032 & 0.60 & 0.90 & 1.00 \\
\hline 19. & Thermal insulation & + & Points & 0.0857 & 0.70 & 0.70 & 0.80 \\
\hline 20. & Heating system & + & Points & 0.1065 & 0.30 & 0.80 & 1.00 \\
\hline 21. & Telephone facilities & + & Points & 0.0147 & 1.00 & 0.90 & 0.90 \\
\hline 22. & Length of fence & + & Meter & 0.0448 & 0.00 & 0.00 & 100.00 \\
\hline 23. & Quality of fence & + & Points & 0.0491 & 0.00 & 0.00 & 0.80 \\
\hline 24. & Equipping of a territory & + & Points & 0.0544 & 0.00 & 0.00 & 0.80 \\
\hline 25. & Total floor space of auxiliary buildings & + & Sq. $\mathrm{m}$ & 0.0205 & 80.00 & 0.00 & 0.00 \\
\hline 26. & Quality of garages, completeness & + & Points & 0.0203 & 0.20 & 0.20 & 0.80 \\
\hline 27. & Number of garages in the house & + & Number & 0.0306 & 1.00 & 2.00 & 2.00 \\
\hline 28. & Other buildings & + & Points & 0.0103 & 0.00 & 0.00 & 0.60 \\
\hline
\end{tabular}

ground of which is clay loam. Form of the plot of land is a regular rectangle; the plot of land is bounding to neighboring plots of land from three sides. The built area of the plot of land covers $160 \mathrm{~m}^{2}$. Two-storey dwelling house is well appointed completely. The dwelling house was erected in 2004, and it includes as follows: 5 rooms, 2 garages, telephone, wood windows of glass package, framed doors, a fire-place equipped, heating by solid fuel, gaseous and electric power. Walls of the building are plastered, puttied and painted, external walls of the building have thermal insulation, and floors are made of wood. The total floor-space of the building makes up $280 \mathrm{~m}^{2}$. The dwelling house is in good condition. First compara- ble single-family dwelling was sold for 360.00 thousand EURO.

\subsection{Description of the second comparable single-family dwelling}

The comparable single-family dwelling is located on district Bukciai in Vilnius, 5 kilometers from the city center, next to the river Neris (0.5 $\mathrm{km})$. The plot of land situated at Ruko Street. Area of the plot of land makes up to 6 ares, the ground of which is sandy loam. Form of the plot of land is a regular rectangle; it is bounding to neighboring plots of land from two sides. The plot of land is equipped. Local sewerage system is available. The built area of the plot of land covers $120 \mathrm{~m}^{2}$. Two-storey dwelling house 
Table 5. Results of single-family dwellings multiple criteria analysis

\begin{tabular}{|c|c|c|c|c|c|}
\hline \multirow[t]{2}{*}{ Criteria } & \multirow[t]{2}{*}{$*$} & \multirow[t]{2}{*}{ Weights } & \multicolumn{3}{|c|}{ Comparable single-family dwellings } \\
\hline & & & 1 & 2 & 3 \\
\hline Selling price & - & 0.8040 & 0.1916 & 0.3032 & 0.3453 \\
\hline Area of land plot & + & 0.2786 & 0.0064 & 0.0119 & 0.0055 \\
\hline Constructed area of land plot & + & 0.0436 & 0.0011 & 0.0014 & 0.0011 \\
\hline Quality of engineering equipment, completeness & + & 0.1138 & 0.0271 & 0.0379 & 0.0488 \\
\hline Accessability to land plot & + & 0.1063 & 0.0105 & 0.0118 & 0.0131 \\
\hline Infrastructure of education and public welfare & + & 0.0372 & 0.0124 & 0.0124 & 0.0124 \\
\hline Industrial territories & - & 0.0464 & 0.0155 & 0.0155 & 0.0155 \\
\hline Local commercial infrastructure & + & 0.0070 & 0.0023 & 0.0023 & 0.0023 \\
\hline Neighborhood & + & 0.0933 & 0.0011 & 0.0011 & 0.0011 \\
\hline District prestige & + & 0.0877 & 0.0292 & 0.0292 & 0.0292 \\
\hline Pollution (emission) & - & 0.1289 & 0.0096 & 0.0096 & 0.0096 \\
\hline Total floor space & + & 0.1686 & 0.0126 & 0.0136 & 0.0116 \\
\hline Age of dwelling & - & 0.0837 & 0.0119 & 0.0179 & 0.0239 \\
\hline Layout of premises & + & 0.0446 & 0.0112 & 0.0112 & 0.0223 \\
\hline Structures, their state & + & 0.1038 & 0.0113 & 0.0113 & 0.0113 \\
\hline Comfortability & + & 0.0564 & 0.0133 & 0.0133 & 0.0299 \\
\hline Internal decoration & + & 0.1124 & 0.0187 & 0.0437 & 0.0500 \\
\hline External decoration & + & 0.1032 & 0.0248 & 0.0372 & 0.0413 \\
\hline Thermal insulation & + & 0.0857 & 0.0273 & 0.0273 & 0.0312 \\
\hline Heating system & + & 0.1065 & 0.0152 & 0.0406 & 0.0507 \\
\hline Telephone facilities & + & 0.0147 & 0.0053 & 0.0047 & 0.0047 \\
\hline Length of fence & + & 0.0448 & 0.0000 & 0.0000 & 0.0448 \\
\hline Quality of fence & + & 0.0491 & 0.0000 & 0.0000 & 0.0491 \\
\hline Equipping of a territory & + & 0.0544 & 0.0000 & 0.0000 & 0.0544 \\
\hline Total floor space of auxiliary buildings & + & 0.0205 & 0.0205 & 0.0000 & 0.0000 \\
\hline Quality of garages, completeness & + & 0.0203 & 0.0034 & 0.0034 & 0.0135 \\
\hline Number of garages in the house & + & 0.0306 & 0.0061 & 0.0122 & 0.0122 \\
\hline Other buildings & + & 0.0103 & 0.0000 & 0.0000 & 0.0103 \\
\hline$S_{+j}$ & & & 0.2610 & 0.3337 & 0.5363 \\
\hline$S_{-j}$ & & & 0.2274 & 0.3390 & 0.4088 \\
\hline$Q_{j}$ & & & 0.6989 & 0.6274 & 0.7799 \\
\hline$N_{j}(\%)$ & & & 89.61 & 80.45 & 100.00 \\
\hline Priority & & & 2 & 3 & 1 \\
\hline Selling price (thousand EURO) & & & 380.00 & 360.00 & 410.00 \\
\hline Market value (thousand EURO) & & & 226.13 & & \\
\hline
\end{tabular}

with a mansard erected in 2003, containing 5 rooms, three sanitation premises, ceiling constructions are made of reinforced concrete, tinplate roof, thermal insulation, braced, windows of glass packet, parquet floor, puttied and painted walls. 2 garages are equipped in the house, a greenhouse, and single telephone line available. The total floor-space of the building makes up $240 \mathrm{~m}^{2}$. Cellar and the mansard are not equipped. The dwelling house is in good con- 
dition. It is possible to expand the plot of land at 7 ares by buying up from the state. Second comparable single-family dwelling was sold for 410.00 thousand EURO.

\subsection{Investigation process and summary of results}

Regarding the main characteristics of qualitative, quantitative and market descriptions of the single-family dwelling under valuation and the comparable single-family dwellings, a grouped decision matrix was formed (Table 4).

Using a grouped decision making matrix (Table 4) and the equations 1-12 the calculations are made. The results of the multiple criteria analysis of the single-family dwellings are given in Table 5.

The market value of the single-family dwelling was estimated in 8 cycles of approximation, until the mean deviation $k_{x}$, of the degree of utility of the single-family dwellings under valuation, calculated in step 7 of the method, satisfied the condition $\left|k_{1}\right|<1 \%$. As it is seen from the Table 6, the calculated initial single-family dwelling value $x_{11-p}$ in the first approach was equated to 380.00 thousand EURO. However in the first approach the accuracy of $\left|k_{11}\right|=-17.95 \%$ was reached instead of the required $1 \%$. In the remaining seven approach stages the calculation accuracy of the single-family dwelling value $\left|k_{1}\right|$ increased $12.50 \%,-7.60 \%,-4.60 \%,-2.75 \%,-1.70 \%,-1.05 \%$ ) until it $\left(\left|k_{18}\right|=|-0.60 \%|\right)$ not exceeded $1 \%$ (Table 6).

\section{CONCLUSION}

The methodology for the defining the utility and market value of a real estate developed by authors has been presented in this paper. The proposed methods, the method of multiple criteria complex proportional assessment (COPRAS) and the method of defining the utility and market value of a real estate assume the dependence of priority, utility degree and value of investigated versions on a system of criteria adequately describing the alternatives and their direct proportionality to the values and weights of these criteria. Using this methodology, a participant/decision maker can evaluate alternatives of the real estate in terms of criteria both qualitative and quantitative. The approach allows evaluating the satisfaction degree of the needs of the participants involved such as buyers, sellers, developers, investors, etc. and the real estate. A sample valuation case study is presented in order to illustrate the use of the developed multiple criteria approach.

Table 6. Estimation of changes in the mean deviation of the degree of utility, the refined value and the market value of the single-family dwelling under valuation

\begin{tabular}{|c|c|c|c|}
\hline $\begin{array}{l}\text { Cycle of } \\
\text { approximation }\end{array}$ & $\begin{array}{l}\text { The corrected value } x_{11-p} \text { of } \\
\text { the single-family dwelling to } \\
\text { be valuated } a_{1} \text { (thousand } \\
\text { EURO) }\end{array}$ & $\begin{array}{l}\left.\text { The accuracy ( }\left|k_{1}\right|<1 \%\right) \text {, to be } \\
\text { achieved in calculating the market } \\
\text { value } x_{11-R} \text { of the single-family } \\
\text { dwelling } a_{1}\end{array}$ & $\begin{array}{l}\text { The market value } x_{11-R} \text { of } \\
\text { the single-family dwelling } \\
a_{1} \text { (thousand EURO) }\end{array}$ \\
\hline 1 & 380.00 & $k_{11}=-17.95 \%$ & \\
\hline 2 & 311.79 & $k_{12}=-12.50 \%$ & \\
\hline 3 & 272.82 & $k_{13}=-7.60 \%$ & \\
\hline 4 & 252.09 & $k_{14}=-4.60 \%$ & \\
\hline 5 & 240.49 & $k_{15}=-2.75 \%$ & \\
\hline 6 & 233.88 & $k_{16}=-1.70 \%$ & \\
\hline 7 & 229.90 & $k_{17}=-1.05 \%$ & \\
\hline \multirow[t]{2}{*}{8} & 227.49 & $k_{18}=-0.60 \%$ & \\
\hline & & & 226.13 \\
\hline
\end{tabular}




\section{REFERENCES}

Arguea, N. M. and Hsiao, C. (2000) Market values of environmental amenities: a latent variable approach. Journal of Housing Economics, 9, p. 104-126.

Baffoe-Bonnie, J. (1998) The dynamic impact of macroeconomic aggregates on housing prices and stock of houses: a national and regional analysis. Journal of Real Estate Finance and Economics, 17(2), p. 179-197.

Bourassa, S. C., Hoesli, M. and Sun, J. (2006) A simple alternative house price index method. Journal of Housing Economics, 15, p. 80-97.

Cannaday, R. E., Munneke, H. J. and Yang, T. T. (2005) A multivariate repeat-sales model for estimating house price indices. Journal of Urban Economics, 57, p. 320-342.

Diappi, L. and Bolchi, P. (2007) Smith's rent gap theory and local real estate dynamics: A multiagent model. Computers, Environment and Urban Systems, In Press.

Dua, P., Miller, S. M. and Smyth, D. J. (1999) Using leading indicators to forecast U.S. home sales in a Bayesian Vector Autoregressive framework. Journal of Real Estate Finance and Economics, 18(2), p. 191-205.

Englund, P., Quigley, J. M. and Redfearn, Ch. L. (1998) Improved price indexes for real estate: measuring the course of Swedish housing prices. Journal of Urban Economics, 44, p. 171196.

Fletcher, M., Gallimore, P. and Mangan, J. (2000) The modeling of housing sub markets. Journal of Property Investment and Finance, 18(4), p. $473-487$.

Framework 5 (2000) Promoting innovation in construction industry SMEs (CONSTRINNONET). Contract IPS 2000-00002.

Framework 5 (2001) Lifetime engineering of buildings and civil infrastructures (LIFETIME). Con-tract GTC1-2001-43046.

Framework 6 (2003) Bringing retrofit innovation to application in public buildings (BRITA in PuBs). Project Reference: EcoBd/503135/2003.

Gibbons, S. and Machin, S. (2003) Valuing English primary schools. Journal of Urban Economics, 53, p. 197-219.

Gonzalez, A. J. and Laureano-Ortiz, R. (1992) A case-based reasoning approach to real estate property appraisal. Expert Systems with Applications, 4(2), p. 229-246.

Huang, F. and Wang, F. (2005) A system for earlywarning and forecasting of real estate development. Automation in Construction, 14(3), p. 333-342.

Hui, E. C. M. and Yu, K. H. (2006) The dynamics of Hong Kong's office rental market. International Journal of Strategic Property Management, 10(3), p. 145-168.

Ioannides, Y. M. (2003) Interactive property valuations. Journal of Urban Economics, 53, p. $145-170$.

Kaklauskas, A. (1996) Improvement of criteria significance determination. Statyba (Civil Engineering), 1(5), p. 64-70.

Kaklauskas, A. (1998) Total life analysis, modeling and forecasting of construction in Lithuania. Research output, Ref.: ACE PHARE programme. Project No.: P96-6708-F.

Kaklauskas, A. (1999) Multiple criteria decision support of building life cycle, Research report presented for habilitation, Vilnius Gediminas Technical University, Vilnius.

Kaklauskas, A. and Gikys, M. (2005) Increasing efficiency of multiple listing service systems applying web-based decision support system for real estate. Journal of Civil Engineering and Management, 11(2), p. 91-97.

Kaklauskas, A., Zavadskas, E. K. and Raslanas, S. (2005) Multivariant design and multiple criteria analysis of building refurbishments. Energy and Buildings, 37(4), p. 361-372.

Kuo, Ch.-l. (1996) Housing price dynamics and the valuation of mortgage default options. Journal of Housing Economics, 5(1), p. 18-40.

Leung, B. Y. P. and Hui, E. C. M. (2000) Real options pricing for property development. Property Management, 4(1), p. 5-22.

Lins, M. P. E., Novaes, L. F. L. and Legey, L. F. L. (2005) Real estate appraisal: a double perspective data envelopment analysis approach. Annals of Operations Research, 138, p. 79-96.

Magdisyuk, I. Using the cascade-correlation algorithm to evaluate investment projects. Informatica, 12(1), 2001, p. 101-108.

Maliene, V., Zavadskas, E., Kaklauskas, A. and Raslanas, S. (1999) Property valuation by multiple criteria methods. Statyba (Civil Engineering), 5(4), p. 272-284 (in Lithuanian). 
Markland, R. E. (1979) A simulation approach to real estate investment analysis. Computers \& Operations Research, 6(3), p. 121-128.

Martinaitis, V., Kazakevičius, E. and Vitkauskas, A. (2007) A two-factor method for appraising building renovation and energy efficiency improvement projects. Energy Policy, 35, p. 192201.

Mendez, F. (2006) The value of legal housing titles: an empirical study. Journal of Housing Economics, 15, p. 143-155.

Miller, E. J., Hunt, J. D., Abraham, J. E. and Salvini, P. A. (2004) Microsimulating urban systems. Computers, Environment and Urban Systems, 28(1-2), p. 9-44.

Ministry of Construction and Urban Development of the Republic of Lithuania (1998) In: Zavadskas, E. K., editor. Report on analysis of housing sector economic effectiveness (in Lithuanian).

Ministry of Economy of the Republic of Lithuania (2001) In: Visokavicius, R., Visokaviciene, B., Zavadskas, E. K., Sedbaras, S., Kaklauskas, A., Banaitis, A., Banaitiene, N. and Trinkunas, V., editors. Development of an export strategy (in Lithuanian). Research reference: No. 202/ 9-S/01; 2001.

Pace, R. K., Barry, R., Gilley, O. W. and Sirmans, C. F. (2000) A method for spatial-temporal forecasting with an application to real estate prices. International Journal of Forecasting, 16(2), p. 229-246.

Trippi, R. R. (1989) A decision support system for real estate investment portfolio management. Information \& Management, 16(1), p. 47-54.
Wang, W. K. (2005) A knowledge-based decision support system for measuring the performance of government real estate investment. Expert Systems with Applications, 29(4), p. 901-912.

Wheaton, W. C., Torto, R. G. and Evans, P. (1997) The cyclic behavior of the Greater London office market. Journal of Real Estate Finance and Economics, 15(1), p. 77-92.

Zavadskas, E. and Kaklauskas, A. (1996) Multiple criteria analysis of buildings, Vilnius (in Lithuanian).

Zavadskas, E. K., Kaklauskas, A. and Malienè, V. (1997) Real estate price evaluation by means of multiple criteria project assessment methods, in Zavadskas, E. K., Sloan, B. and Kaklauskas, A. (eds.), Proceedings of the international conference on property valuation and investment in Central and Eastern Europe during the transition to free market economy, Vilnius, pp. 156-170.

Zavadskas, E. K., Kaklauskas, A., Raslanas, S. and Maliene, V. (2001) The application of multiplecriterion methods for valuation of recreation property. Statyba (Civil Engineering), 7(4), p. 327-333 (in German).

Zavadskas, E. K., Kaklauskas, A., Raslanas, S. and Krutinis, M. (2004a) Pecularities of multi-criteria e-trade system application in real estate sector. Journal of Civil Engineering and Management, 10(Suppl. 1) p. 71-78 (in Lithuanian).

Zavadskas, E. K., Kaklauskas, A., Banaitis, A. and Kvederyte, N. (2004b) Housing credit access model: the case for Lithuania. European Journal of Operational Research, 155(2), p. 335-352. 


\section{SANTRAUKA}

DAUGIAKRITERINIS NEKILNOJAMOJO TURTO NAUDINGUMO LAIPSNIO IR VERTĖS NUSTATYMAS

\section{Artūras KAKLAUSKAS, Edmundas K. ZAVADSKAS, Audrius BANAITIS, Gintautas ŠATKAUSKAS}

Straipsnyje aprašomas daugiakriterinis nekilnojamojo turto naudingumo laipsnio ir vertès nustatymas pagal autorių siūlomus metodus: daugiakriterinị kompleksinio proporcingo ịvertinimo ir daugiakriterinį naudingumo laipsnio ir vertės nustatymo metodą. Nagrinejamų nekilnojamojo turto variantų prioritetiškumas ir reikšmingumas tiesiogiai ir proporcingai priklauso nuo alternatyvas adekvačiai apibūdinančių kriterijų sistemos, kriterijų reikšmių ir reikšmingumų dydžių. Naudingumo laipsnis rodo suinteresuotų grupių pasiektų tikslų lygị. Todẻ juo remiantis nustatoma nekilnojamojo turto vertė. Atsižvelgus ị visų analizuojamų nekilnojamojo turto alternatyvų naudingumo laipsnius, skaičiuojama konkretaus nekilnojamojo turto (alternatyvos) verte. Remiantis pateiktais metodais, buvo nustatyta vienbučio gyvenamojo namo rinkos vertė. 